\title{
Stem Cells for Neonatal Lung Disease Caused by SP-B Deficiency?
}

\author{
Stammzellen bei neonatalen Lungenerkrankungen verursacht durch SP-B Mangel?
}

Ludwig Gortner

Bibliography

DOI http://dx.doi.org/

$10.1055 / \mathrm{s}-0034-1395697$

Klin Padiatr 2015; 227: 1-2

(c) Georg Thieme Verlag KG

Stuttgart $\cdot$ New York

ISSN 0300-8630

Correspondence

Prof. Dr. Ludwig Gortner

Clinics for Paediatrics and

Adolescent Medicine

University Hospital of

the Saarland

Building 9

66421 Homburg

Germany

ludwig.gortner@uks.eu
Recent reports confirm the serious consequences of partial surfactant protein B (SP-B) deficiency in a heterozygous SP-B121ins2 mutation [1], the homozygous form of this specific mutation initially had been described by the group of Nogee and co-workers in a term neonate with intractable respiratory failure about 20 years ago [13]. Before this substantial contribute to our understanding of genetic pulmonary disorders with neonatal onset, the clinical entity was described as idiopathic pulmonary alveolar proteinosis [12]. The disorder was characterized by an uniform lethal course [12]. Medical and physical approaches to improve the course of the disease included among others administration of surfactant, corticosteroids and other immunosuppressants, repeated lung lavage and ultimately lung transplantation. Medical attempts were not successful at long-term and lung transplants in neonates and young infants, if available, were reported to be overall accompanied by a high rate complications [8-10]. Thus, also a recent report confirms that SP-B deficiency is a devastating diagnosis in neonates with irreversible respiratory failure [18]. A recently published observational study conducted between 2006 and 2011 from the UK showed that out of 427 cases with unclear severe neonatal respiratory failure, 25 cases could be identified to suffer from surfactant dysfunction disorders, i.e. about $6 \%$ overall. SP-B dysfunction could be confirmed in 8 cases and furthermore, 3 affected individuals with SP-B deficiency following prenatal diagnostic were reported. All aforementioned neonates with disorders in the surfactant $B$ system died from intractable respiratory failure [15]. A recent report from China on SP-B gene mutations in an autochthonous cohort indicates that the genetic variation may be more prevalent in far eastern populations then reported before from western Caucasian populations $[3,18]$. Thus, as an adequate therapy for neonates suffering from SP-B deficiency is still lacking and given the fact that it has been described in a high number of individuals from the Chinese Han population, both aspects may further underline the magnitude of the clinical problem. It might further be aggravated due to a high number of undiagnosed cases [7].

Previous reports indicating that lung transplantation might a therapeutic option suffer from poor long-time outcome [14] apart from not being overall available. Thus, on a global perspective, the impact of SP-B gene mutations leading to absence or dysfunctional protein still might be more relevant than anticipated before.
Recent experimental reports indicate that stem cell therapy in various respiratory disorders was effective to improve pulmonary histology, morphometry and various gene and biochemical variables [5]. Most experimental studies in bronchopulmonary dysplasia, i.e. a typical neonatal respiratory disorder indicate that mesenchymal stem cells either given by the systemic route or by intratracheal administration are efficient to improve histologic and biochemic features. Thus, experimentally induced bronchopulmonary dysplasia (BPD) may serve as a typical model of chronic neonatal lung disorder [6]. Furthermore, reports on experimentally induced acute respiratory distress syndrome in adult animals by various noxious stimuli to the lung have been published previously [4]. Most transplants were given as allogenic mesenchymal stem cells, some other groups also used cell xenotransplants obtained from human preterm neonates [11]. Homing of stem cells in the lungs at a variable extent and transformation of mesenchymal and hematopoietic stem cells into type II alveolar cells have been reported nearly uniformly [16].

A first clinical phase I study using allogenous mesenchymal stem cells in very preterm neonates with threatening BPD has been published recently by a Korean group [2]. Thus, there is now a high degree of experimental evidence that stem cell administration is effective in experimentally induced respiratory failure in neonates as well as in adults and as a consequence, the Korean group started a clinical study based on several experimental studies.

Given these fact SP-B deficiency may be considered as a further field for research on regenerative therapy i.e. stem cell administration in models of postnatal SP-B deficiency. If the findings of these experiments will be positive, this distinct disorder could be considered a further candidate for stem cell administration during the neonatal period. Due to the unique fatal course of SP-B deficiency in neonates, they might be excellent candidates for regenerative therapies. Before coming into clinical reality however, a number of experimental data on safety and efficacy needs to be worked out further. Long-term outcome of the preterm neonates, who were enrolled in the above mentioned phase I trial from Korea using allogenous mesenchymal stem cells in threatening bronchopulmonary dysplasia should be considered as one key issue [2]. If successful in SP-B deficiency, other disorders in surfactant homeostasis, e.g. ABCA3-defects may be addressed further [17]. 


\section{References}

1 Baekvad-Hansen $M$, Dahl M, Tybjaerg-Hansen A et al. Surfactant protein-B 121ins2 heterozygosity, reduced pulmonary function, and chronic obstructive pulmonary disease in smokers. Am J Respir Crit Care Med 2010; 181: 17-20

2 Chang YS, Ahn SY, Yoo HS et al. Mesenchymal stem cells for bronchopulmonary dysplasia: phase 1 dose-escalation clinical trial. J Pediatr 2014; 164: 966.e6-972.e6

3 Cole FS, Hamvas A, Rubinstein P et al. Population-based estimates of surfactant protein B deficiency. Pediatrics 2000; 105: 538-541

4 Cribbs SK, Martin GS. Stem cells in sepsis and acute lung injury. Am J Med Sci 2011; 341: 325-332

5 Gortner L, Felderhoff-Muser U, Monz D et al. Regenerative therapies in neonatology: clinical perspectives. Klin Padiatr 2012; 224: 233-240

6 Gortner L, Tutdibi E, Meyer S. Stammzelltherapie in der Neonatologie. Monatsschr Kinderheilkd 2014; 162: 792-797

7 Hamvas A. Inherited surfactant protein-B deficiency and surfactant protein- $C$ associated disease: clinical features and evaluation. Semin Perinatol 2006; 30: 316-326

8 Hamvas A, Cole FS, deMello DE et al. Surfactant protein B deficiency: antenatal diagnosis and prospective treatment with surfactant replacement. J Pediatr 1994; 125: 356-361

9 Hamvas A, Nogee LM, deMello DE et al. Pathophysiology and treatment of surfactant protein-B deficiency. Biol Neonate 1995; 67 (Suppl 1): 18-31
10 Huddleston C, Mendeloff E, Mallory G. Pediatric lung transplantation. An Esp Pediatr 2001; 54: 359-371

11 Monz D, Tutdibi E, Mildau C et al. Human umbilical cord blood mononuclear cells in a double-hit model of bronchopulmonary dysplasia in neonatal mice. PLoS One 2013; 8: e74740

12 Nogee LM. Surfactant protein-B deficiency. Chest 1997; 111: 129S-135S

13 Nogee LM, Garnier G, Dietz HC et al. A mutation in the surfactant protein $B$ gene responsible for fatal neonatal respiratory disease in multiple kindreds. J Clin Invest 1994; 93: 1860-1863

14 Palomar LM, Nogee LM, Sweet SC et al. Long-term outcomes after infant lung transplantation for surfactant protein B deficiency related to other causes of respiratory failure. J Pediatr 2006; 149: 548-553

15 Turcu S, Ashton E, Jenkins L et al. Genetic testing in children with surfactant dysfunction. Arch Dis Child 2013; 98: 490-495

16 Weiss DJ, Bertoncello I, Borok $Z$ et al. Stem cells and cell therapies in lung biology and lung diseases. Proc Am Thorac Soc 2011; 8: 223-272

17 Winter J, Essmann S, Kidszun A et al. Neonatal respiratory insufficiency caused by an (homozygous) ABCA3-stop mutation: a systematic evaluation of therapeutic options. Klin Padiatr 2014; 226: 53-58

18 Yin X, Meng F, Wang $Y$ et al. Surfactant protein B deficiency and gene mutations for neonatal respiratory distress syndrome in China Han ethnic population. Int J Clin Exp Pathol 2013; 6: 267-272 